\title{
Carbon-isotope stratigraphy recorded by the Cenomanian-Turonian Oceanic Anoxic Event: correlation and implications based on three key localities
}

\author{
H. TSIKOS ${ }^{1,5}$, H.C. JENKYNS ${ }^{1}$, B. WALSWORTH-BELL ${ }^{2}$, M.R. PETRIZZO ${ }^{2}$, A. FORSTER ${ }^{3}$, \\ S. KOLONIC ${ }^{4}$, E. ERBA ${ }^{2}$, I. PREMOLI SILVA ${ }^{2}, \mathrm{M} \mathrm{BAAS}^{3}$, T. WAGNER ${ }^{4} \&$ \\ J.S. SINNINGHE DAMSTÉ ${ }^{3}$ \\ ${ }^{1}$ Department of Earth Sciences, University of Oxford, Parks Road, Oxford OX1 3PR, UK \\ ${ }^{2}$ Ardito Desio Department of Earth Sciences, University of Milan, via L. Mangiagalli 34, 20133 Milan, Italy \\ ${ }^{3}$ Department of Marine Biogeochemistry and Toxicology, Royal Netherlands Institute of Sea Research (NIOZ), 1790 AB \\ Den Burg, The Netherlands \\ ${ }^{4}$ Department of Geosciences, University of Bremen, Bremen, Germany \\ ${ }^{5}$ Present address: Department of Geology \& Petroleum Geology, University of Aberdeen, Aberdeen AB2 3UE, UK \\ (e-mail: h.tsikos@abdn.ac.uk)
}

\begin{abstract}
We present new, detailed carbon-isotope records for bulk carbonate, total organic carbon (TOC) and phytane from three key sections spanning the Cenomanian-Turonian boundary interval (Eastbourne, England; Gubbio, Italy; Tarfaya, Morocco), with the purpose of establishing a common chemostratigraphic framework for Oceanic Anoxic Event (OAE) 2. Isotope curves from all localities are characterized by a positive carbon-isotope excursion of c. $4 \%$ for TOC and phytane and c. $2.5 \%$ for carbonate, although diagenetic overprinting appears to have obliterated the primary carbonate carbon-isotope signal in at least part of the Tarfaya section. Stratigraphically, peak $\delta^{13} \mathrm{C}$ values for all components are followed by intervals of high, near-constant $\delta^{13} \mathrm{C}$ in the form of an isotopic plateau. Recognition of an unambiguous return to background $\delta^{13} \mathrm{C}$ values above the plateau is, however, contentious in all sections, hence no firm chemostratigraphic marker for the end-point of the positive isotopic excursion can be established. The stratigraphically consistent first appearance of the calcareous nannofossil Quadrum gartneri at or near the Cenomanian-Turonian boundary as established by ammonite stratigraphy, in conjunction with the end of the $\delta^{13} \mathrm{C}$ maximum characteristic of the isotopic plateau, provides a potentially powerful tool for delimiting the stratigraphic extent and duration of OAE 2. This Oceanic Anoxic Event is demonstrated to be largely, if not wholly, confined to the latest part of the Cenomanian stage.
\end{abstract}

Keywords: Oceanic Anoxic Event 2, Eastbourne, England, Gubbio, Italy, Tarfaya, Morocco, ${ }^{13} \mathrm{C}$.

The concept of Oceanic Anoxic Events (OAEs), as introduced in the mid-1970s (Schlanger \& Jenkyns 1976), hinged upon the discovery of widely distributed, apparently coeval, organic carbon-rich sediments deposited across a range of marine settings, from shelf seas to the open ocean. The Cenomanian-Turonian $(\mathrm{C}-\mathrm{T})$ boundary interval records a classic example of an OAE because it is typified by the development of organic carbon-rich deposits on a global scale, with a concomitant positive shift in carbon-isotope values in marine carbonate and marine and terrestrial organic matter (e.g. Arthur et al. 1988; Hasegawa 1997). This positive $\delta^{13} \mathrm{C}$ shift is conventionally related to excess burial of organic carbon (Jenkyns 1980; Scholle \& Arthur 1980; Schlanger et al. 1987). The C-T OAE (hereafter referred to as 'OAE 2') or Bonarelli Event (named after the Livello Bonarelli or Bonarelli Level, the characteristic black shale cropping out in the Marche-Umbrian Apennines of central Italy) constitutes an ideal candidate for detailed investigations of the changing environmental conditions behind the establishment of widespread marine anoxia during specific intervals of geological time.

In this paper, we re-examine in detail the carbon-isotope stratigraphy of three key, outcrop/drill-core sections spanning the C-T interval from England, Italy and Morocco (Fig. 1). New, high-resolution total organic carbon (TOC) records and stableisotope data from total carbonate and organic carbon in all sections have been obtained on a centimetre- to decimetre-scale.

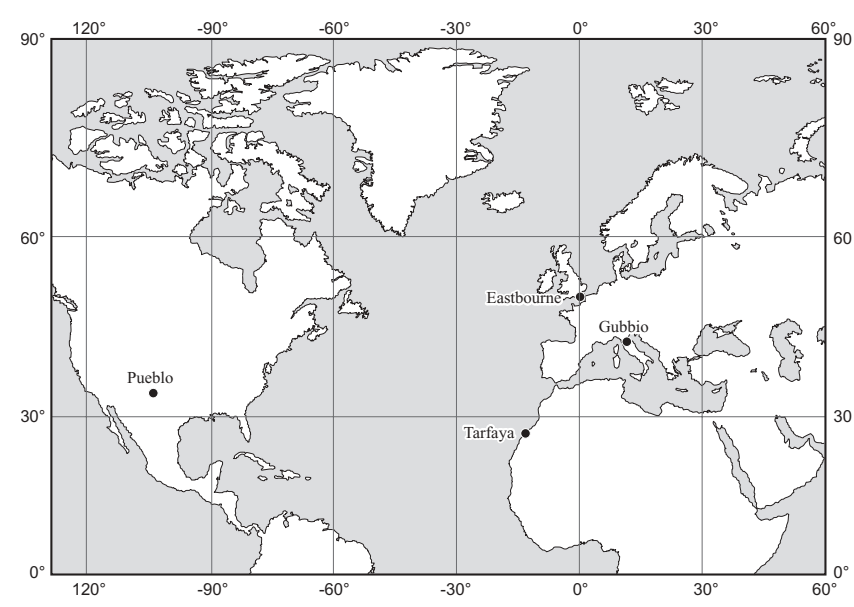

Fig. 1. Locality map showing the three sites selected for this paper and the Pueblo locality, the proposed global stratotype for the CenomanianTuronian boundary (Kennedy et al. 2000).

These records were complemented by compound-specific $\delta^{13} \mathrm{C}$ data for free as well as sulphur-bound phytane at lower stratigraphic resolution. Phytane is an organic compound (acyclic isoprenoid) that is predominantly derived from the phytol side- 
chain of phytoplanktonic chlorophyll- $\alpha$, and therefore represents a useful proxy for the isotopic composition of ancient marine phytoplankton communities (e.g. Kohnen et al. 1992; Kuypers et al. 1999, 2002). The carbon-isotope curves are calibrated against new calcareous nannofossil and planktonic foraminiferal biostratigraphy, and compared with published chemo- and biostratigraphic data from Pueblo (Colorado, USA; Fig. 1), the proposed stratotype section for the C-T boundary (Kennedy et al. 2000). Our objectives are two-fold: (1) to generate a universal chemostratigraphic framework for OAE 2 by comparing and contrasting the various isotopic records from the different sites; (2) to highlight the advantages and limitations of using detailed carbon-isotope stratigraphy as an independent correlative tool for constraining the stratigraphic extent and duration of OAE 2.

\section{Selected sites and methods}

Three representative sections spanning the $\mathrm{C}-\mathrm{T}$ boundary interval were selected for this investigation, namely Eastbourne (East Sussex, England), Tarfaya (SW Morocco) and Gubbio (Umbria, Italy) (Fig. 1). The Eastbourne section was logged and sampled wholly at the Gun Gardens locality between November 2000 and August 2001, and thus represents an improvement on composite sections from the same area published previously (e.g. Gale et al. 1993; Paul et al. 1999; Keller et al. 2001). A core (S57) representing $\mathrm{C}-\mathrm{T}$ sediments at Tarfaya (drilled by Shell during exploration in the late 1970s to early 1980s) was logged and sampled in October 2001 at the Ocean Drilling Program Core Repository in Bremen, Germany, where it is currently stored. At Gubbio, two cores (S2 and S4) were drilled in the Vispi Quarry in the Contessa Valley during June 2000. These cores are stored at the Ardito Desio Department of Earth Sciences, University of Milan, and were logged and sampled between October 2000 and March 2001. Sampling intervals ranged from $20-40 \mathrm{~cm}$ for the material from Eastbourne and Tarfaya, to $c .10 \mathrm{~cm}$ for the limestones from Gubbio, whereas the organic-rich Bonarelli Level was sampled on a more detailed centimetre to sub-centimetre scale.

Values of wt.\% TOC were determined on organic-rich samples from the Gubbio and Tarfaya sections, and on a few, organic-lean samples from the Plenus Marls unit at Eastbourne, using techniques described by Jenkyns (1988) and Kolonic et al. (2002). Carbonate (C, O) and total organic carbon (TOC) isotope ratios were determined on powdered bulkrock samples from all three sites, using standard analytical techniques at Oxford University, as detailed elsewhere (Jenkyns et al. 1994). Selected powdered samples from the Tarfaya and Gubbio sections were also solvent-extracted with a mixture of dichloromethane-methanol $(9: 1, \mathrm{v} / \mathrm{v})$, and the total lipid extracts were separated by column chromatography into polar and apolar fractions, and the latter into saturated and unsaturated fractions. In the case of the core samples from Gubbio, compound-specific $\delta^{13} \mathrm{C}$ measurements on phytane present in the saturated apolar fractions were obtained using isotope-ratio monitoring gas chromatography-mass spectrometry (IRM-GC-MS) at the Royal Netherlands Institute of Sea Research (NIOZ). For the Tarfaya core samples, the polar fractions were first treated by Raney Nickel desulphurization, to release sulphur-bound hydrocarbons, followed by column separation and hydrogenation of the apolar fractions to yield phytane. All compoundspecific carbon-isotope measurements were carried out at least in duplicate, and the mean $\delta^{13} \mathrm{C}$ values for each sample are presented in the usual $\delta$ notation versus the VPDB standard. The analytical quality of the IRM-GC-MS was monitored by adding an internal standard of known isotopic composition for every individual sample injection.

Nannofossil biostratigraphy was generated using standard techniques (Bown \& Young 1998). Smear slides were studied under the light microscope, and nannofossil abundance and preservation determined using qualitative categories. Planktonic foraminiferal biostratigraphy was generated for the Plenus Marls Member (Eastbourne) and Tarfaya sections using washed residues. Samples were soaked in hydrogen peroxide, washed under running water through $63-150 \mu \mathrm{m}, 150-250 \mu \mathrm{m}$ and $>250 \mu \mathrm{m}$ sieves, and then dried. Ultrasonic treatment was used to clean specimens, facilitating identification. The harder lithologies of the
Eastbourne Grey Chalk Member and White Chalk Formation, and of the Gubbio section, were studied in thin section.

\section{Results}

\section{Eastbourne, East Sussex (England)}

The Gun Gardens section at Eastbourne is the most expanded Cenomanian-Turonian section in the Anglo-Paris Basin, and has been the subject of detailed bio- and chemostratigraphic studies (e.g. Gale et al. 1993; Paul et al. 1999; Keller et al. 2001). The same section has also been proposed as the European reference section for the $\mathrm{C}-\mathrm{T}$ interval (Paul et al. 1999). The succession consists of three, broadly defined lithological units, namely (from bottom to top): Grey Chalk Member, Plenus Marls Member and White Chalk Formation (Fig. 2). Lithological variations between these three units are essentially related to the interplay of two end-member components, i.e. $\mathrm{CaCO}_{3}$ (mainly as nannofossils) and clay. The Grey Chalk contains common intercalations of thin, marly layers, with omnipresent bioturbation. The Plenus Marls consist of greenish grey marls and clay-rich chalks in the basal part, progressively grading to purer chalk alternating with decimetre-thick marl layers upwards in the section. The White Chalk comprises hard, nodular to gritty chalks separated by centimetre-thick marl flasers in the lower parts, with the latter becoming less common stratigraphically upwards.

Results for bulk carbonate carbon and oxygen isotopes across a $27 \mathrm{~m}$ thick outcrop section at Gun Gardens are presented in Figure 2. Nannofossil and planktonic foraminiferal biostratigraphy is also provided. The lowermost $6 \mathrm{~m}$ (Grey Chalk) are characterized by essentially constant $\delta^{13} \mathrm{C}_{\text {carb }}$ values of c. $3 \%$. A distinct rise in $\delta^{13} \mathrm{C}_{\text {carb }}$ occurs at the base of the Plenus Marls, with a first maximum of c. $4.8 \%$ occurring at about $4 \mathrm{~m}$ above the contact with the Grey Chalk; this is immediately followed by a small dip in values of $c$. $0.5 \%$. A second, positive isotopic 'spike' (c. 5.4\% ) occurs higher in the succession, close to the contact with the overlying White Chalk. The remaining part of the section (White Chalk) records essentially constant values of c. $4.8 \%$ for about $4-5 \mathrm{~m}$, followed by a smooth decline in the uppermost c. $8 \mathrm{~m}$, to $\delta^{13} \mathrm{C}_{\text {carb }}$ values of less than $4 \%$.

Bulk carbonate $\delta^{18} \mathrm{O}$ data show considerable variation across the entire stratigraphy, yet they register a progressive shift to lower $\delta^{18} \mathrm{O}$ values near the second $\delta^{13} \mathrm{C}_{\text {carb }}$ maximum, from $c$. $-3 \%$ in the Grey Chalk-Plenus Marls interval, to -3.5 to $-4 \%$ o in the overlying White Chalk Formation. This broad pattern is interrupted by small-scale positive excursions just below and within the Plenus Marls, and has previously been interpreted as a palaeotemperature signal, with short-term cooling 'events' superimposed on a general warming trend (Jenkyns et al. 1994).

The Eastbourne section contains very little organic carbon, in most cases below the detection limit of the instrumental analytical techniques used in this study. The Plenus Marls unit was selected for isotopic analyses of its organic-carbon fraction, because of its lower bulk carbonate/clay ratio and thus potentially higher TOC content. Bulk TOC values were nevertheless very low throughout the Plenus Marls interval (0.1-0.2 wt.\%) with a maximum of 0.26 wt.\% (this study) recorded in Bed 6 (Fig. 2) of Gale et al. (1993). Bulk organic-carbon $\delta^{13} \mathrm{C}$ $\left(\delta^{13} \mathrm{C}_{\mathrm{TOC}}\right)$ data presented in Figure 2 were obtained from 31 samples, beginning from the base of the Plenus Marls, up to (and including) one sample from Bed 6. Despite the very low TOC contents, reproducibility of data was in the range $\pm 0.3-0.5 \%$. By comparison with the $\delta^{13} \mathrm{C}_{\text {carb }}$ data over the same interval, $\delta^{13} \mathrm{C}_{\mathrm{TOC}}$ values show little similarity, although both record a 


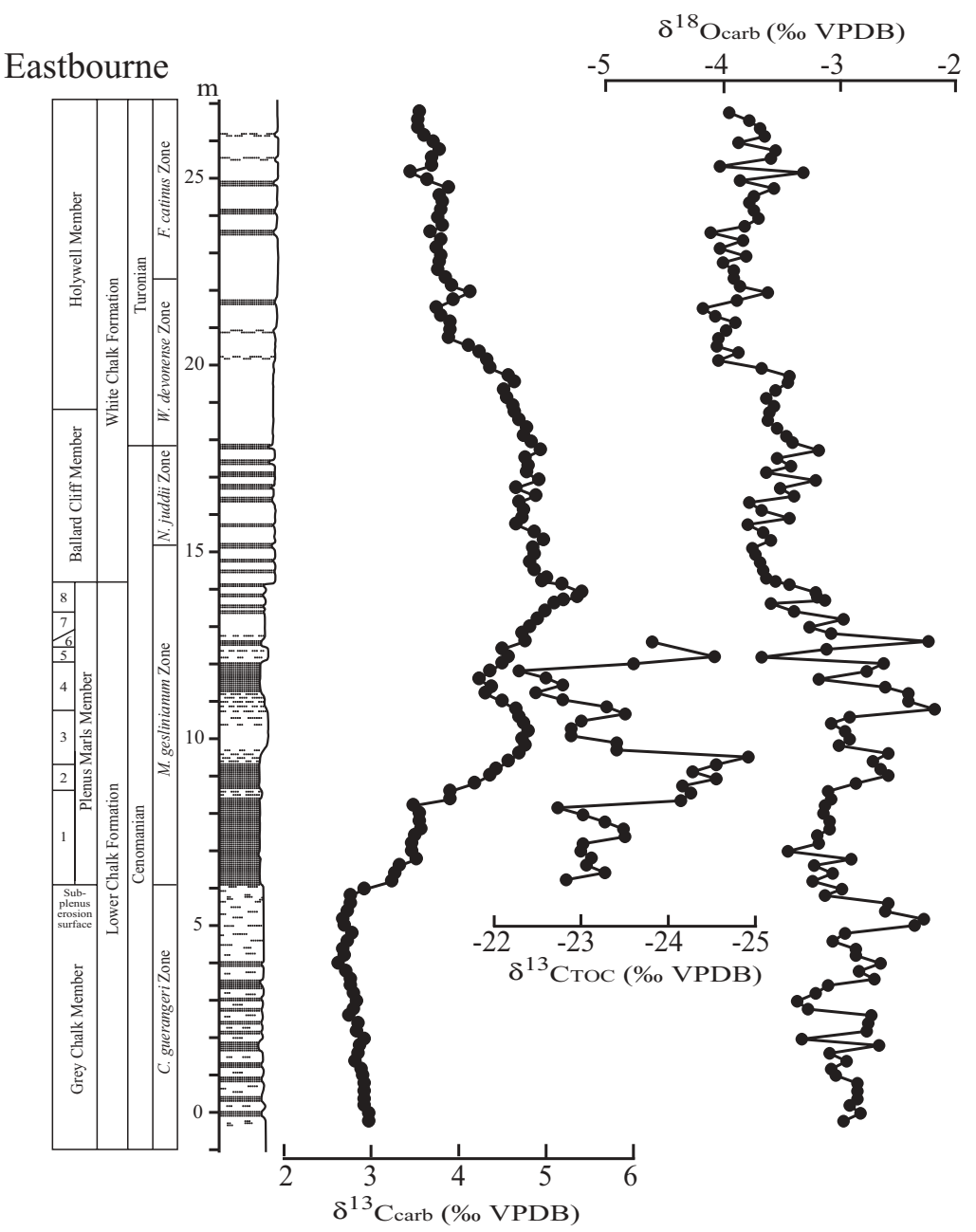

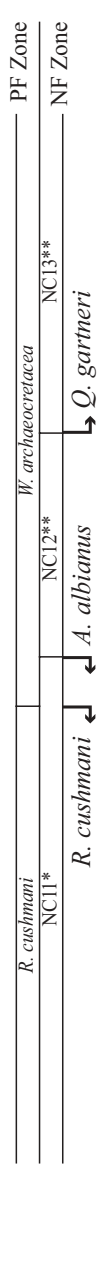

Fig. 2. Carbon- and oxygen-isotope stratigraphy and biostratigraphy of the Eastbourne section, East Sussex, England. Chalk intervals are shown as blank, marls as stippled. PF, planktonic foraminiferal; $\mathrm{NF}$, nannofossil. Zone $\mathrm{NC} 11^{*}$ from the zonation of Bralower et al. (1995). c. $2 \%$ increase at a comparable stratigraphic level to that of the first carbonate carbon-isotope peak. Nevertheless, the possibility exists that such a trend may be related to other causes such as, for example, variable contributions of terrestrial v. marine organic matter, changes in the aquatic primary biomass productivity and/or changes in dissolved carbon dioxide content (e.g. Arthur et al. 1988).

\section{Gubbio, Umbria (Italy)}

The stratigraphically continuous pelagic carbonate succession of the upper Albian to Santonian Scaglia Formation (Scaglia Bianca and Scaglia Rossa) has been the subject of several investigations (e.g. Arthur \& Premoli Silva 1982; Jenkyns et al. 1994; Stoll \& Schrag 2000). The Scaglia Bianca encloses the Bonarelli Level, a striking, c. $1 \mathrm{~m}$ thick unit of millimetre-laminated black shale and radiolarian sand (Arthur \& Premoli Silva 1982) representing the sedimentary expression of OAE 2 . Gubbio is the type locality for the Bonarelli Level.

The Bonarelli Level has a thickness of $c .82 \mathrm{~cm}$ in $\mathrm{S} 4$, the core that yielded the optimum recovery of this unit. (We take the Bonarelli Level, which has not been formally defined, to be the whole limestone-free interval, including the lowermost chert and the uppermost radiolarian sand (sensu Arthur \& Premoli Silva 1982).) Stratigraphically, TOC contents vary widely and reach maximum values of up to $25-26 \mathrm{wt} . \%$ in the uppermost portion (between 10 and $25 \mathrm{~cm}$ below the stratigraphic top; see Fig. 3).
Bulk $\mathrm{CaCO}_{3}$ contents throughout the Bonarelli Level are either very low $(<5 \mathrm{wt} . \%)$ or below the limit of detection.

$\delta^{13} \mathrm{C}_{\mathrm{TOC}}$ values of $c .-25 \%$ characterize the lowermost $15 \mathrm{~cm}$ of the Bonarelli Level, but they rise sharply by c. $1-1.5 \%$ as TOC values reach their first maximum of $c .15$ wt.\% (Fig. 3). Thereafter, the $\delta^{13} \mathrm{C}_{\mathrm{TOC}}$ data show little variation throughout the remainder of the unit, apart from a relative minimum between 30 and $45 \mathrm{~cm}$ (Fig. 3). Highest isotopic values ( -23.0 to $-22.5 \%$ ) are observed in the uppermost portion of the Bonarelli Level, and coincide with the interval where highest TOC values also occur. Lower-resolution phytane $\delta^{13} \mathrm{C}\left(\delta^{13} \mathrm{C}_{\mathrm{Ph}}\right)$ data (Fig. 3) essentially mimic the $\delta^{13} \mathrm{C}_{\text {TOC }}$ pattern, with values of c. $-29 \%$ in the lower part of the Bonarelli Level, progressively increasing to maxima of -28 to $-27.5 \%$ stratigraphically upwards.

The Scaglia Bianca Formation, which encloses the Bonarelli Level, is a micritic limestone containing abundant solutionwelded nannofossils and planktonic foraminifera and common intercalations of chert and local, millimetre-scale marl seams. Isotopic variations across the $36.64 \mathrm{~m}$ thick $\mathrm{S} 2$ core section compare well with previously published curves (e.g. Stoll \& Schrag 2000) and are shown in the stratigraphic plots of Figure 4. $\delta^{13} \mathrm{C}_{\text {carb }}$ values show a first maximum of c. $3 \%$, at $c .20 \mathrm{~m}$ below the base of the Bonarelli Level, which must correspond to the 'Mid-Cenomanian Event' (Jenkyns et al. 1994; Coccioni \& Galeotti 2003). Thereafter, values progressively decline to isotopic minima of c. $2.3 \%$ over a stratigraphic interval of $5-6 \mathrm{~m}$, gradually rise to an average value of c. $2.6 \%$, and remain 


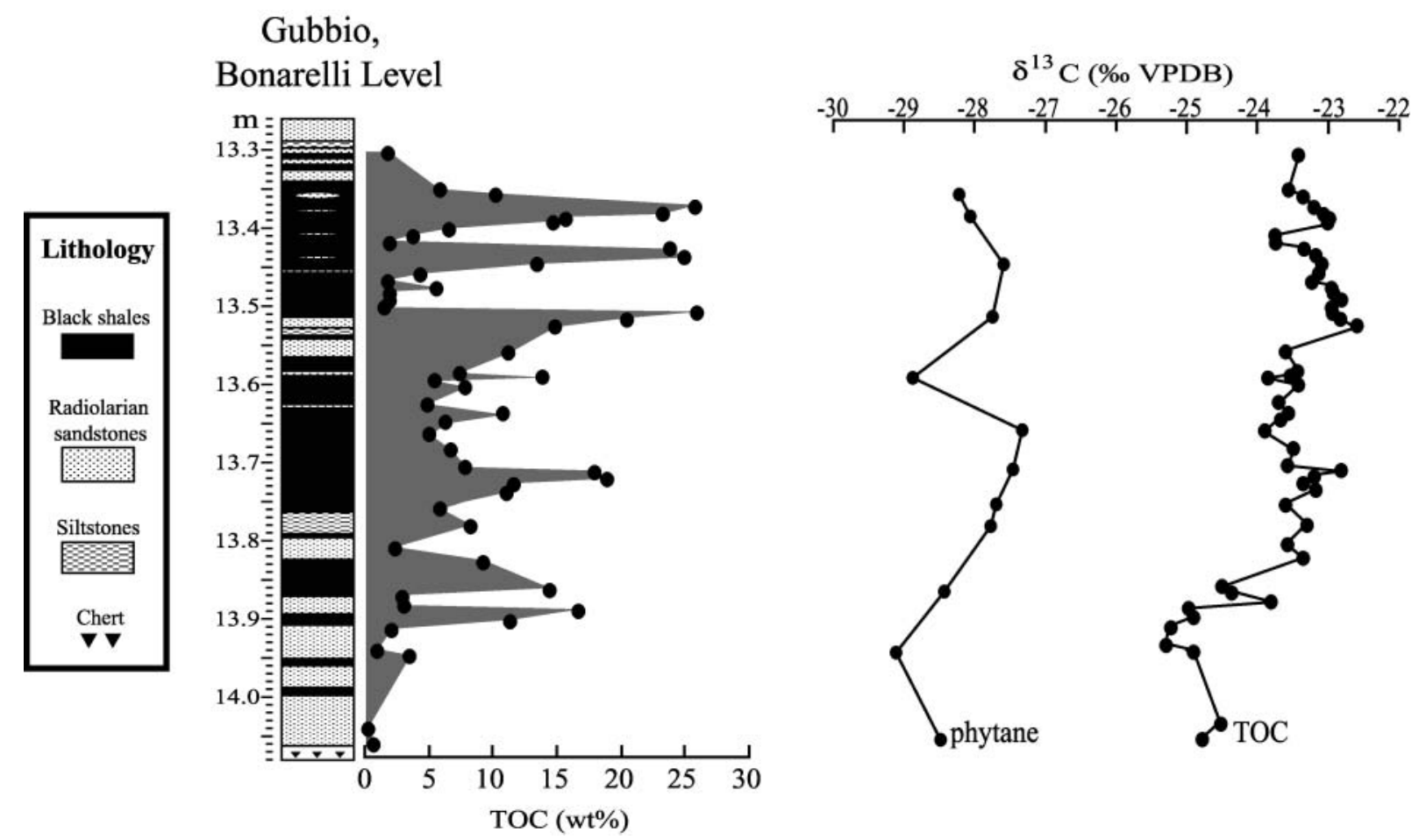

Fig. 3. Total organic carbon (TOC), $\delta^{13} \mathrm{C}_{\mathrm{TOC}}$ and $\delta^{13} \mathrm{C}_{\mathrm{Ph}}$ stratigraphic profiles across the Bonarelli Level, S4 core, Gubbio, Italy.

essentially constant for the uppermost $10 \mathrm{~m}$ of section below the Bonarelli Level. Immediately above the latter, $\delta^{13} \mathrm{C}_{\text {carb }}$ values are the highest seen in the Gubbio section, with an average value of c. $3.2 \%$ prevailing over c. $1.5 \mathrm{~m}$ of stratigraphic thickness. Above this interval, values decline to $<3 \%$, and show little variation for the uppermost $10 \mathrm{~m}$ of the section, including the transition from the Scaglia Bianca (white limestone) to the Scaglia Rossa (reddish limestone) Formations at $4.27 \mathrm{~m}$ stratigraphic depth (Fig. 4).

Bulk carbonate $\delta^{18} \mathrm{O}$ data show considerable scatter throughout the Scaglia section, possibly resulting from post-depositional diagenetic modification. Nevertheless, the data do record a slight lowering in average $\delta^{18} \mathrm{O}$ values of $c .0 .3 \%$, between the suband supradjacent Bonarelli Level sediments, which could indicate an overall rise in temperature over this interval (Fig. 4).

Formulation of a complete nannofossil and planktonic foraminiferal biostratigraphy for the Gubbio section is hindered by the virtual absence of carbonate in the Bonarelli Level. As a result, although the key marker species Axopodorhabdus albianus (Black) (nannofossil) and Rotalipora cushmani (Morrow) (planktonic foraminifer) are last encountered immediately below this unit, it is likely that their true last occurrences fall within the black shale itself. The first appearance of the marker nannofossil Quadrum gartneri Prins \& Perch-Nielsen is observed at c. $1 \mathrm{~m}$ above the Bonarelli Level, and is thus not affected by this preservational problem.

\section{Tarfaya (SW Morocco)}

The Tarfaya Basin in SW Morocco is host to an exceptionally thick (up to $800 \mathrm{~m}$ ) organic matter-rich, shallow-marine sedimentary succession spanning the mid-Cretaceous, including perhaps the most stratigraphically expanded $\mathrm{C}-\mathrm{T}$ interval known (Luderer \& Kuhnt 1997). It has therefore been the subject of several studies (e.g. Kuhnt et al. 1997, 2001; El Albani et al. 1999; Kolonic et al. 2002). The section investigated here (core S57) comprises c. $37 \mathrm{~m}$ of organic-rich calcareous sediment, characterized by rhythmic alternations of decimetre-scale, darkand light-coloured layers separated by gradational contacts. In terms of TOC content, individual samples vary from less than $1 \mathrm{wt} . \%$ to more than $20 \mathrm{wt} . \%$, whereas total carbonate, finely dispersed silica and lesser clay are the other dominant components throughout the section.

Bulk-rock TOC and $\delta^{13} \mathrm{C}_{\text {carb }}, \delta^{13} \mathrm{C}_{\mathrm{TOC}}$ and $\delta^{13} \mathrm{C}_{\mathrm{Ph}}$ data are shown in Figure 5, along with nannofossil and planktonic foraminiferal biostratigraphy. The $\delta^{13} \mathrm{C}_{\mathrm{TOC}}$ curve exhibits a characteristic positive excursion, from values between -27 and $-26 \%$ for the lowermost $4 \mathrm{~m}$ of the core, to $c$. $-23 \%$ at about $53 \mathrm{~m}$ below surface. The excursion culminates in two distinct, closely spaced isotopic peaks, separated by a c. 1\%o 'trough'. Thereafter, the data form an isotopic 'plateau' of $\delta^{13} \mathrm{C}$ values around $-24 \%$, and this spans the portion of the succession wherein a peak in TOC content is also observed. At $c .9 \mathrm{~m}$ stratigraphically above the second isotope spike, $\delta^{13} \mathrm{C}_{\mathrm{TOC}}$ values begin to decline, and stabilize around the value of $-26 \%$ or the remaining part of the section.

Phytane and, to a much lesser extent, total carbonate $\delta^{13} \mathrm{C}$ data, show some important similarities with, and differences from the $\delta^{13} \mathrm{C}_{\text {TOC }}$ curve. Probably the most important reproducible feature in all three curves is the progressive increase in $\delta^{13} \mathrm{C}$ values by c. 4\%o for phytane and TOC, and 2.5-3\%o for bulk carbonate, beginning from c. $56 \mathrm{~m}$ and $54 \mathrm{~m}$ below surface, respectively, and extending for 3-5 m stratigraphically upwards. However, these isotopic peaks appear to be slightly offset in relation to each other. Furthermore, definition of a true positive excursion plateau in the $\delta^{13} \mathrm{C}_{\text {carb }}$ curve is clearly problematic, owing to the highly variable nature of the data from both above and below the interpreted isotopic maxima. This ill-defined 


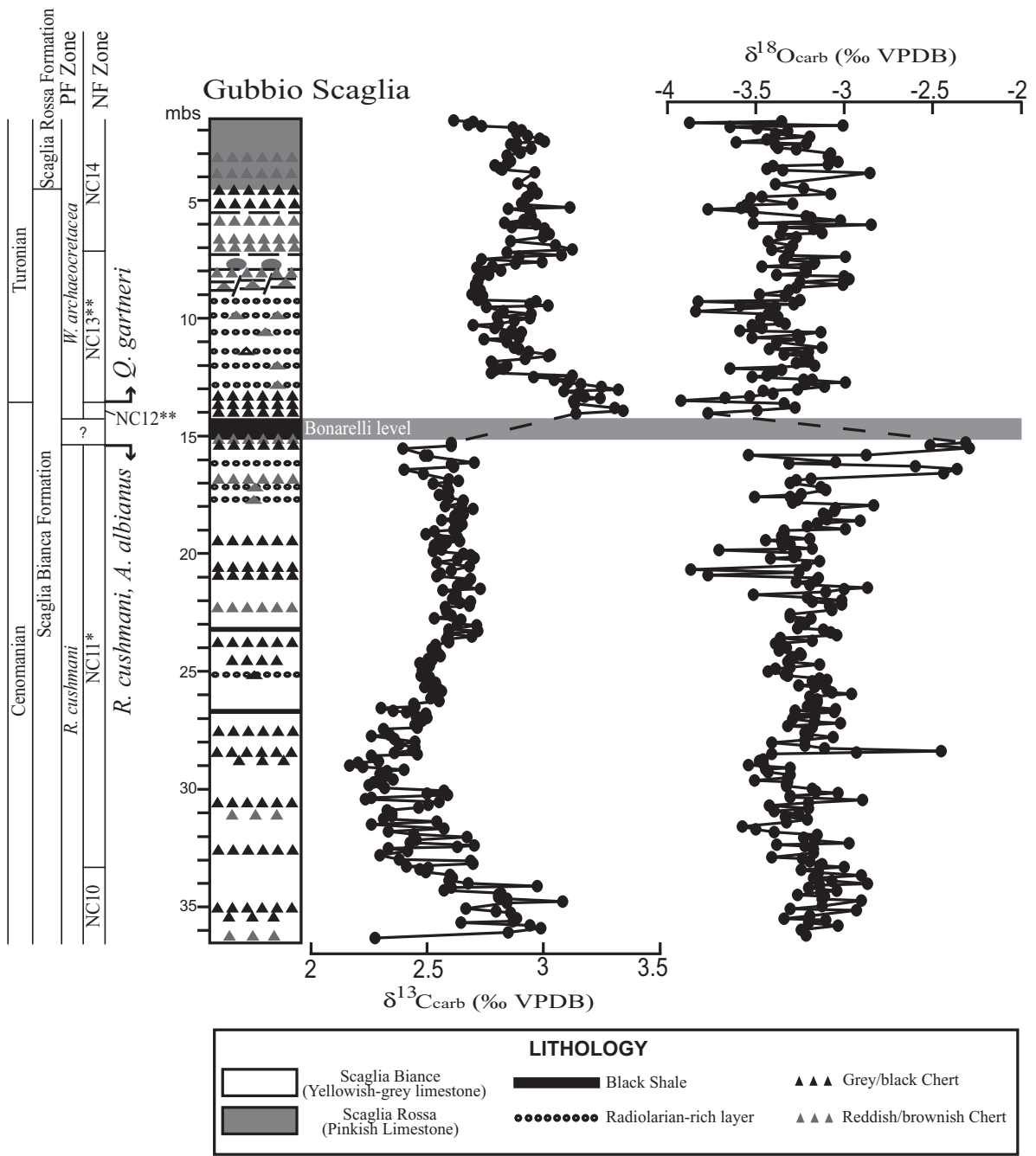

Fig. 4. Carbonate carbon- and oxygenisotope stratigraphy and biostratigraphy of the Scaglia Bianca and Scaglia Rossa formations in the Gubbio S2 core. PF, planktonic foraminiferal; NF, nannofossil. Zones $\mathrm{NC10}$ and $\mathrm{NC14}$ from the zonation of Roth (1978); NC11* from that of Bralower et al. (1995). C-T boundary placed using the first occurrence of the nannofossil $Q$. gartneri. mbs, metres below surface. excursion is possibly related to early diagenetic overprinting caused by the transfer of isotopically light carbon from bacterial degradation of organic matter to carbonate cement (e.g. Scholle \& Arthur 1980). Diagenetic effects are also believed to be responsible for the variable degrees of calcareous nannofossil and planktonic foraminiferal preservation, observed across the entire Tarfaya section. Curiously, although carbonate $\delta^{18} \mathrm{O}$ data are usually the most susceptible to post-depositional isotopic exchange, the bulk carbonate $\delta^{18} \mathrm{O}$ profile shows a consistent upward decrease by c. $1.5 \%$ across the Tarfaya profile, although whether or not these data actually record primary geochemical signals related to palaeotemperature trends and/or changes in the evaporation-precipitation balance in seawater is unknown.

With respect to the $\delta^{13} \mathrm{C}_{\mathrm{Ph}}$ profile, although relatively constant values characterize the interval $51-39 \mathrm{~m}$ in concert with the observed plateau of the $\delta^{13} \mathrm{C}_{\mathrm{TOC}}$ curve, no clear return towards pre-excursion values is observed thereafter. The narrow trough of $\delta^{13} \mathrm{C}_{\mathrm{Ph}}$ values between 39 and $38 \mathrm{~m}$ below surface, which is also seen in the $\delta^{13} \mathrm{C}_{\mathrm{TOC}}$ curve, coincides with a corresponding drop in TOC values and may reflect some degree of local control on the global signal.

\section{Synthesis}

A compilation of the carbon-isotope profiles and biostratigraphic data as presented above is shown in Figure 6. Of critical importance here is the comparison between our new data and existing chemo- and biostratigraphic information from the proposed stratotype section for the Cenomanian-Turonian boundary at Pueblo, Colorado, USA (Pratt \& Threlkeld 1984; Watkins 1985; Gale et al. 1993; Pratt et al. 1993; Kennedy et al. 2000). Special emphasis is placed on the reproducibility of salient features of the isotopic profiles across the different sites, and the importance of these in defining potentially global chemostratigraphic markers, both for delimiting the stratigraphic extent of OAE 2 and for the placement of the Cenomanian-Turonian boundary. Evaluation of data is undertaken on the premise that an oceanic anoxic event such as OAE 2 is, by definition, a perturbation of the global marine inorganic-organic carbon reservoirs as a result of excess burial of organic matter. Therefore, such an event must be reflected in the isotopic record of respective sedimentary products, as long as local watermass effects and post-depositional processes have not obliterated the preservation of primary marine chemical signals. All carbonaterich successions analysed are dominated by the nannofossil Watznaueria; hence the potential of 'vital effects' (related to changing relative proportions of different species through time) to affect the bulk isotopic signal is deemed minimal.

It is important to note that the chemostratigraphic delimitation of the extent of OAE 2 offers a more reliable alternative to the original lithostratigraphic definition based on the presence of coeval organic-rich horizons in the $\mathrm{C}-\mathrm{T}$ interval (Schlanger \& 

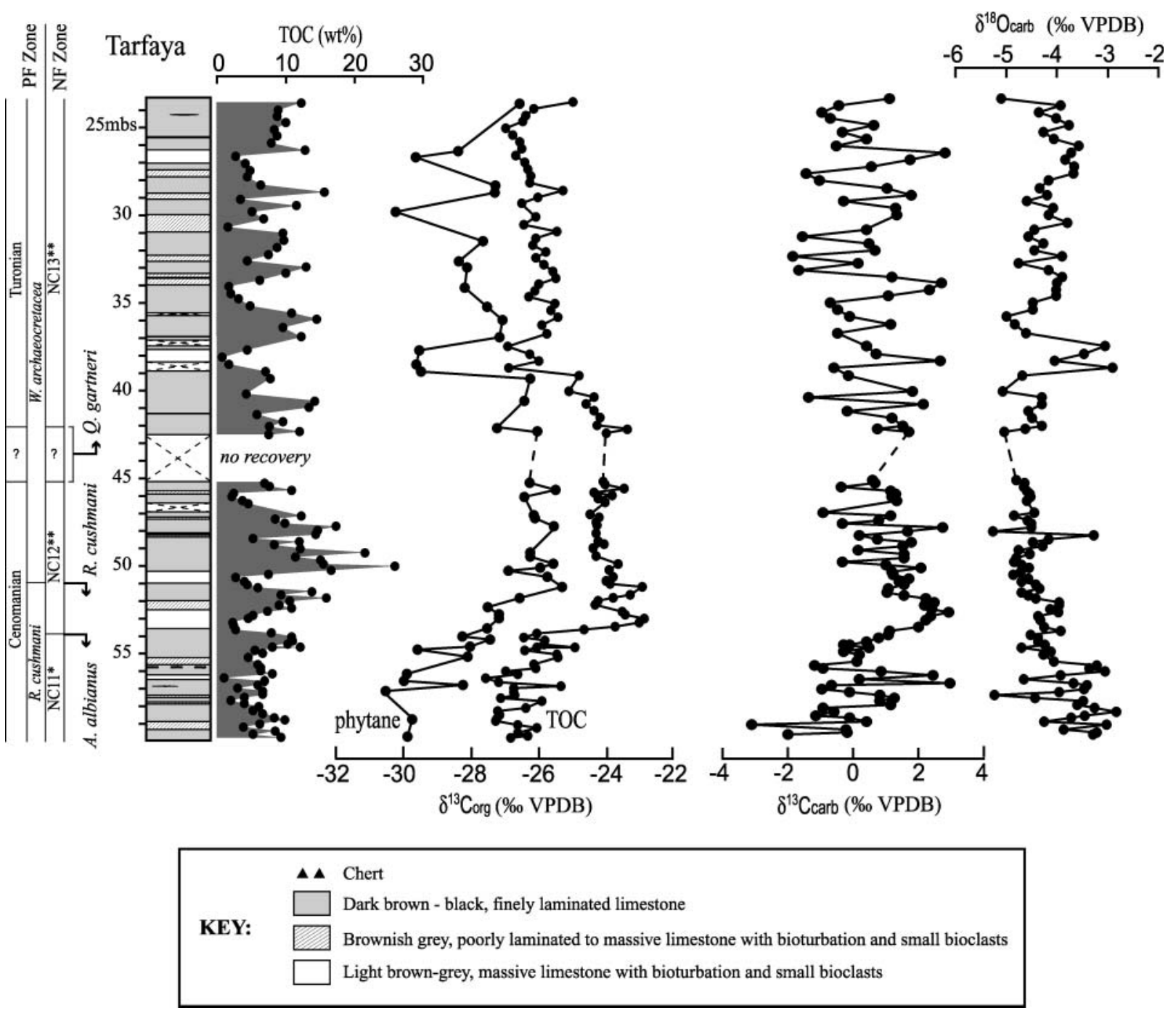

Fig. 5. Stable-isotope chemostratigraphy and biostratigraphy of the Tarfaya S57 core. PF, planktonic foraminiferal; NF, nannofossil. Zone NC11* from the zonation of Bralower et al. (1995). C-T boundary placed using the first occurrence of the nannofossil Q. gartneri.

Jenkyns 1976). The use of carbon isotopes as a proxy for globally enhanced organic-carbon sequestration is applicable to sites not characterized by enrichment in organic matter (e.g. Eastbourne). Furthermore, as is particularly evident if the Pueblo section is compared with the others, the most organic-rich and/or carbonate-poor horizons may be significantly diachronous when considered against integrated chemo- and biostratigraphy (Fig. 6), probably reflecting the unique interaction between local palaeoceanographic and diagenetic conditions at each site and the global event. That said, cross-calibration of the $\delta^{13} \mathrm{C}_{\mathrm{TOC}}$ curves from Eastbourne and Gubbio suggests that the Plenus Marls and Bonarelli Level are essentially coeval. The increase in clay content of the Plenus Marls, relative to the beds above and below, could therefore be a response to a regional rise in nutrient levels that favoured production of organic-walled plankton at the expense of calcareous nannoplankton.

Earlier comparisons between the isotope profiles of TOC from Pueblo and total carbonate from Eastbourne (Gale et al. 1993) demonstrated a complex, but broadly comparable $\delta^{13} \mathrm{C}$ curve geometry across the $\mathrm{C}-\mathrm{T}$ boundary interval, comprising three distinct positive isotope spikes. Calibration of both curves using ammonite stratigraphy (Gale et al. 1993) revealed that the
Cenomanian-Turonian boundary corresponds to the uppermost of these spikes. Our new, higher resolution isotope profile for Eastbourne compares well with that presented by Paul et al. (1999), the most detailed produced to date, in that it shows the curve to be somewhat more complex than a simple three-pronged excursion. Instead, we observe an initial rise in $\delta^{13} \mathrm{C}_{\text {carb }}$ values to form a smooth peak, followed by a slight decline and a further rise to a peak of maximum values that defines the beginning of a broader plateau. These features represent the beginning and maximum isotopic expression of OAE 2 , and are followed by a subsequent gradual drop towards pre-excursion values. A reappraisal of the Pueblo and Eastbourne curves of Figure 6 in conjunction with the existing ammonite stratigraphy indicates that, in relation to the $\mathrm{C}-\mathrm{T}$ boundary, a critical point in both isotope profiles is the level coinciding with the stratigraphically highest maximum $\delta{ }^{13} \mathrm{C}_{\mathrm{TOC}}$ and $\delta{ }^{13} \mathrm{C}_{\text {carb }}$ value, respectively. This level essentially marks the end-point of the main isotopic plateau, which would, in theory, also represent the end of OAE 2, as expressed by the positive carbon-isotope anomaly (see also Kuypers et al. 2002).

In the light of the above observations, we have calibrated the isotopic profiles of the remaining two sites (i.e. Tarfaya and 


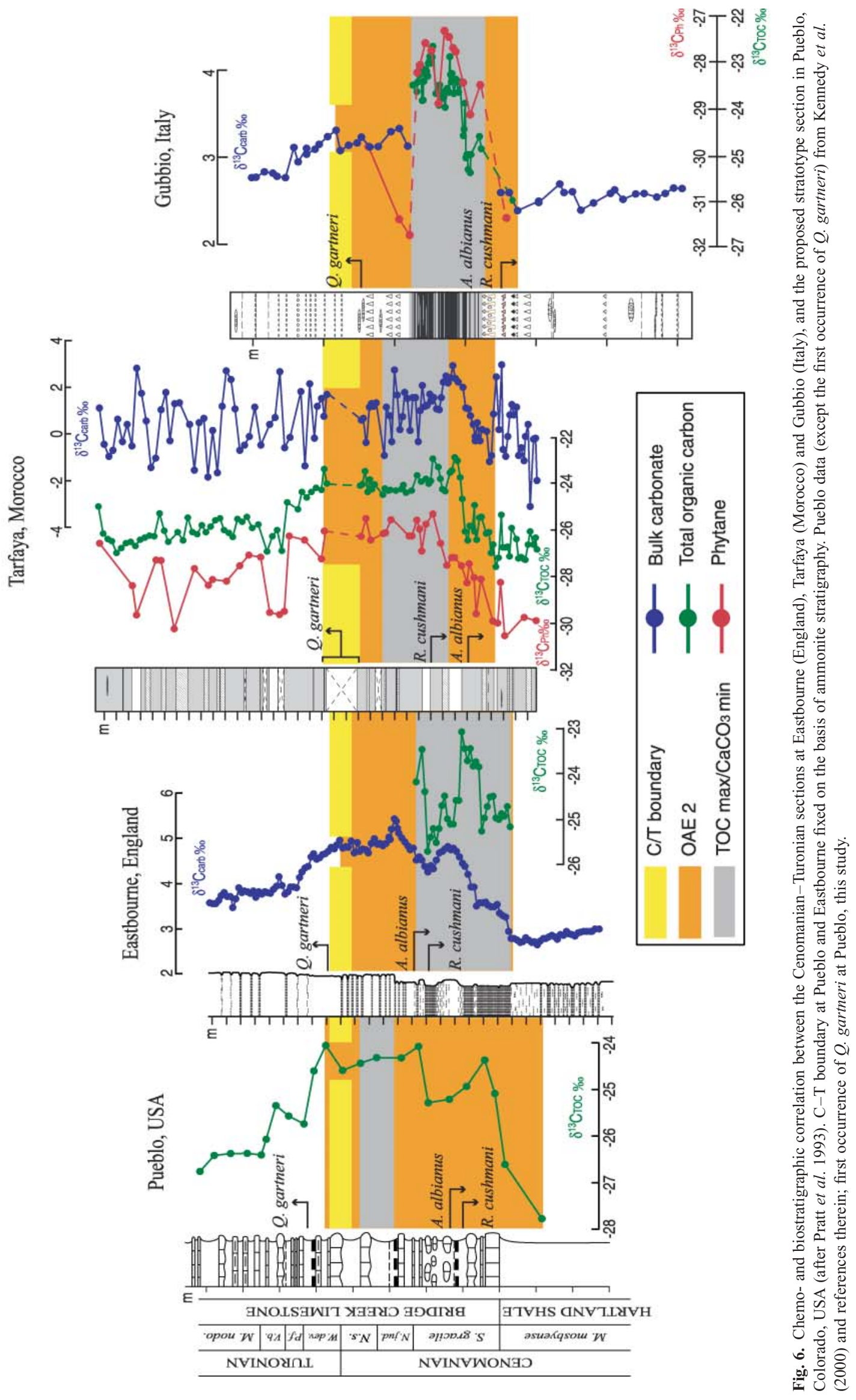


Gubbio) against those for Eastbourne and Pueblo. The diverse lithological character of the Gubbio section (i.e. pelagic carbonate enveloping essentially carbonate-free black shale), however, has required a combination of the existing profiles in a composite stratigraphic framework (Fig. 6). Construction of the composite profile has been aided by a few additional TOC and phytane $\delta^{13} \mathrm{C}$ data for extremely TOC-lean carbonate samples from within the Scaglia formation, collected immediately above and below the Bonarelli unit (Fig. 6). Interpretations of the composite Gubbio chemostratigraphic profile rest on the assumption that changes in the $\delta^{13} \mathrm{C}$ values of marine organic and inorganic materials during OAE 2 largely reflect the isotopic composition of the dissolved inorganic carbon (DIC) reservoir, as controlled by increased global burial rates of isotopically light organic matter. This simplifying assumption facilitates the discussion that follows, but does not take into account other factors that may also affect the composition of bulk organic matter such as, for example, changes in the dissolved carbon dioxide content of the surface ocean (e.g. Arthur et al. 1988) and/or productivity-related changes in fractionation between DIC and biomass (Hayes 2001, and references therein; Kuypers et al. 2002).

Figure 6 demonstrates that the Tarfaya and Gubbio isotopic profiles share some important similarities with the profiles from Eastbourne and Pueblo. In both Tarfaya and Gubbio, a sharp rise in $\delta^{13} \mathrm{C}$ values of $3-4 \%$ is now evident for both TOC and phytane, in a similar fashion to the $\delta^{13} \mathrm{C}_{\mathrm{TOC}}$ record for Pueblo. Furthermore, high $\delta^{13} \mathrm{C}_{\mathrm{TOC}}$ and $\delta^{13} \mathrm{C}_{\mathrm{Ph}}$ values with little variation persist in both sections stratigraphically above the early isotopic maxima (spikes), resulting in the development of isotopic plateaux. However, the combination of individual records makes the stratigraphic definition of the end-points of these positive excursions rather unclear. In the Pueblo section, the $\delta^{13} \mathrm{C}_{\mathrm{TOC}}$ curve appears to return sharply to near pre-excursion values immediately above the $\mathrm{C}-\mathrm{T}$ boundary as defined by ammonite stratigraphy (i.e. first occurrence of the species Watinoceras devonense Wright \& Kennedy; Kennedy et al. 2000, see Fig. 6), although the available record is of low resolution and may not have captured the entire isotopic anomaly. All $\delta^{13} \mathrm{C}$ records for the Tarfaya section are somewhat inconclusive in defining such a drop at any specific stratigraphic level, and this is particularly the case with the carbonate $\delta^{13} \mathrm{C}$ profile. Similarly, the scarcity of $\delta^{13} \mathrm{C}_{\mathrm{TOC}}$ and $\delta^{13} \mathrm{C}_{\mathrm{Ph}}$ values below and above the Bonarelli Level in the Gubbio section also precludes their use in establishing a concrete stratigraphic marker for the end-point of the isotopic excursion. It is likely, however, that the interval of relatively higher values of $\delta^{13} \mathrm{C}_{\text {carb }}$ immediately above the black shale represents an extension of the positive isotopic anomaly into the limestones above. In that case, the end of the plateau may be tentatively placed at $c .1 \mathrm{~m}$ above the stratigraphic top of the Bonarelli Level (Fig. 6).

In summary, it appears that the two most conspicuous features of all isotopic profiles, namely the onset of the excursions and plateau of maximum $\delta^{13} \mathrm{C}$ values, are sufficiently reproducible across all individual sections (Fig. 6) to allow a reasonably objective stratigraphic definition for at least the beginning and maximum isotopic expression of OAE 2. Chemostratigraphic definition of the end-point of the isotopic excursion, however, is clearly more contentious, but it appears that the last $\delta^{13} \mathrm{C}$ plateau maximum may well represent the most suitable chemostratigraphic marker. The first appearance of the nannofossil $Q$. gartneri, an independent biostratigraphic marker (Fig. 6), coincides reasonably well in all sections, not only with the proposed end-point of the isotopic excursion, but also with the $\mathrm{C}-\mathrm{T}$ boundary as defined by ammonite stratigraphy. Consequently, this bioevent constitutes a particularly useful supplementary datum level for placing both the $\mathrm{C}-\mathrm{T}$ boundary and the end of OAE 2, especially in those cases where isotopic profiles fail to provide conclusive stratigraphic resolution.

\section{Conclusions}

Carbon-isotope records for total organic carbon, phytane and total carbonate from three contrasting Cenomanian-Turonian sections, at Eastbourne in England, Gubbio in Italy and Tarfaya in Morocco, offer a global chemostratigraphic framework for the $\mathrm{C}-\mathrm{T}$ Oceanic Anoxic Event. The onset of the isotopic anomaly, representing the initial increase in organic-matter burial rates, is clearly demonstrated by a rapid rise in $\delta^{13} \mathrm{C}$ values for TOC and phytane by $c$. $4 \%$, and for total carbonate, by c. $2.5 \%$. The development of an isotopic plateau of near-constant, high $\delta^{13} \mathrm{C}$ values stratigraphically above the initial excursion is also evident in all sections examined.

Nevertheless, a number of limitations regarding the use of carbon-isotope profiles as a global chemostratigraphic tool have also been highlighted. Although the carbonate record in Eastbourne seems to be devoid of major post-depositional alteration, diagenetic modification in the isotopic composition of sedimentary carbonate in the Tarfaya section appears to have had a profound effect in obscuring the primary isotopic signal. TOC and phytane $\delta^{13} \mathrm{C}$ profiles, albeit showing some similarities, also provide rather inconclusive evidence in terms of chemostratigraphic application. Despite capturing the onset and maximum expression of the positive isotopic anomaly associated with OAE 2 , these records preclude formulation of a precise chemostratigraphic definition of the end-point of the excursion, probably as a consequence of local variations in organic-carbon productivity or preservation obscuring the global isotopic signal. The first appearance of the nannofossil $Q$. gartneri near the $\mathrm{C}-\mathrm{T}$ boundary, used in conjunction with the interpreted end-point of the isotopic plateau, provides a useful supplementary stratigraphic tool in this regard.

Invariably, integration of high-resolution carbon-isotope records and detailed biostratigraphy will constitute an essential requirement for all future studies that strive to link worldwide $\mathrm{C}-\mathrm{T}$ sections under a common stratigraphic framework. In this instance, the OAE can be demonstrated to be largely, if not wholly, confined to the lattermost part of the Cenomanian Stage. Moreover, the most reliable chemostratigraphic and biostratigraphic records across the $\mathrm{C}-\mathrm{T}$ boundary clearly derive from Eastbourne, supporting the proposal that it be considered a European reference section for this interval (Paul et al. 1999).

This work is supported by the European Community's Improving Human Potential Program through the project 'C/T-Net-Rapid global change during the Cenomanian/Turonian oceanic anoxic event: examination of a natural climatic experiment in earth history', under contract HPRN-CT1999-00055, C/T-Net. Our results were produced in the wider context of C/T-Net research activities, and the contribution of all other network partners is gratefully acknowledged. In addition, we thank J. Cartlidge, T. O'Conell, R. M. Corfield and S. Wyatt (Oxford) for assisting with the isotopic and bulk TOC analyses, and D. Sansom (Oxford) for the preparation of the Eastbourne stratigraphic log and of Figure 1. Reviews by S. Nederbragt and R. D. Pancost greatly improved the manuscript. We are also grateful to Shell for providing our research group with Tarfaya core S57.

\section{References}

Arthur, M.A. \& Premoli Silva, I. 1982. Development of widespread organic carbon-rich strata in the Mediterranean Tethys. In: Schlanger, S.O. \& CiTA, 
M.B. (eds) Nature and Origin of Cretaceous Carbon-Rich Facies. Academic Press, London, 7-54.

Arthur, M.A., Dean, W.E. \& Pratt, L.M. 1988. Geochemical and climatic effects of increased marine organic carbon burial at the Cenomanian/Turonian boundary. Nature, 335, 714-717.

Bown, P.R. \& Young, J.R. 1998. Techniques. In: Bown, P.R. (ed.) Calcareous Nannofossil Biostratigraphy. Chapman and Hall, London, 16-28.

Bralower, T.J., Leckie, R.M., Sliter, W.V. \& Thierstein, H.R. 1995. An integrated Cretaceous microfossil biostratigraphy. In: BERGGREN, W.A., Kent, D.V., Aubry, M.P. \& Hardenbol, J. (eds) Geochronology, Time Scales and Global Stratigraphic Correlation. Society of Economic Paleontologists and Mineralogists, Special Publications, 54, 65-79.

Coccioni, R. \& Galeotti, S. 2003. The Mid-Cenomanian Event: prelude to OAE 2. Palaeogeography, Palaeoclimatology, Palaeoecology, 190, 427-440.

El Albani, A., Kuhnt, W., Luderer, F., Herbin, J.P. \& Caron, M. 1999. Palaeoenvironmental evolution of the Late Cretaceous sequence in the Tarfaya Basin (southwest of Morocco). In: CAMERon, N.R., BAte, R.H. \& Clure, V.S. (eds) The Oil and Gas Habitats of the South Atlantic. Geological Society, London, Special Publications, 153, 223-240.

Gale, A.S., Jenkyns, H.C., Kennedy, W.J. \& Corfield, R.M. 1993. Chemostratigraphy versus biostratigraphy: data from around the Cenomanian/Turonian boundary. Journal of the Geological Society, London, 150, 29-32.

Hasegawa, T. 1997. Cenomanian-Turonian carbon isotope events recorded in terrestrial organic matter from northern Japan. Palaeogeography, Palaeoclimatology, Palaeoecology, 130, 251-273.

Hayes, J.M. 2001. Fractionation of carbon and hydrogen isotopes in biosynthetic processes. In: VAlley, J.W. \& Cole, D.R. (eds) Stable Isotope Geochemistry. Mineralogical Society of America, Reviews in Mineralogy and Geochemistry, 43, 225-277.

Jenkyns, H.C. 1980. Cretaceous anoxic events: from continents to oceans. Journal of the Geological Society, London, 137, 171-188.

JENKyns, H.C. 1988. The early Toarcian (Jurassic) anoxic event: stratigraphic, sedimentary, and geochemical evidence. American Journal of Science, 288, $101-151$.

Jenkyns, H.C., Gale, A.S. \& CoRfield, R.M. 1994. Carbon- and oxygen-isotope stratigraphy of the English Chalk and Italian Scaglia and its palaeoclimatic significance. Geological Magazine, 131, 1-34.

Keller, G., Han, Q., Adatte, T. \& Burns, S.J. 2001. Palaeoenvironment of the Cenomanian/Turonian at Eastbourne, England. Cretaceous Research, 22, 391-422.

Kennedy, W.J., Walaszczyk, I. \& Cobban, W.A. 2000. Pueblo, Colorado, USA, candidate Global Boundary Stratotype Section and point for the base of the Turonian stage of the Cretaceous, and for the base of the middle Turonian substage, with a revision of the Inoceramidae (Bivalvia). Acta Geologica Polonica, 50, 295-334.

Kohnen, M.E.L., Schouten, S., Sinninghe Damsté, J.S., De Leeuw, J.W., Merritt, D.A. \& Hayes, J.M. 1992. Recognition of paleobiochemicals by a combined molecular sulfur and isotope geochemical approach. Science, 256, 358-362.

Kolonic, S., Sinninghe Damsté, J.S. \& Böttcher, M.E. et AL. 2002. Geochemical characterization of Cenomanian/Turonian black shales from the Tarfaya Basin (SW Morocco): relationships between palaeoenvironmental conditions and early sulphurization of sedimentary organic matter. Journal of Petroleum Geology, 25, 325-350.
Kuhnt, W., Nederbragt, A. \& Leine, L. 1997. Cyclicity of Cenomanian/ Turonian organic-rich sediments in the Tarfaya Atlantic Coastal Basin (Morocco). Cretaceous Research, 18, 587-601.

Kuhnt, W., Chellai, El H. \& Holbourn, A. et al. 2001. Centennial records of Cretaceous paleoceanographic events and sea-level fluctuations in the Moroccan Tarfaya-Layoune basin. EOS Transactions, American Geophysical Union, 82, 32.

Kuypers, M.M.M., Pancost, R.D. \& Sinninghe Damsté, J.S. 1999. A large and abrupt fall in atmospheric $\mathrm{CO}_{2}$ concentration during Cretaceous times. Nature, 399, 342-345.

Kuypers, M.M.M., Pancost, R.D., Nijenhuis, I.A. \& Sinninghe Damsté, J.S 2002. Enhanced productivity led to increased organic carbon burial in the euxinic North Atlantic basin during the Cenomanian/Turonian oceanic anoxic event. Paleoceanography, 17, 1-13.

Luderer, F. \& Kunnt, W. 1997. A high resolution record of the Rotalipora extinction in laminated organic-carbon rich limestones of the Tarfaya Atlantic coastal basin (Morocco). Annales de la Société Géologique du Nord, 5, 199-205.

Paul, C.R.C., Lamolda, M.A., Mitchell, S.F., Vaziri, M.R., Gorostidi, A. \& Marshall, J.D. 1999. The Cenomanian/Turonian boundary at Eastbourne (Sussex, UK): a proposed European reference section. Palaeogeography, Palaeoclimatology, Palaeoecology, 150, 83-121.

Pratt, L.M. \& Threlkeld, C.N. 1984. Stratigraphic significance of ${ }^{13} \mathrm{C} /{ }^{12} \mathrm{C}$ ratios in mid-Cretaceous rocks of the Western Interior, U.S.AO In: Sтотт, D.F. \& GLass, D.J. (eds) The Mesozoic of Middle North America. Canadian Society of Petroleum Geologists, Memoirs, 9, 305-312.

Pratt, L.M., Arthur, M.A., Dean, W.E. \& Scholle, P.A. 1993. Paleoceanographic cycles and events during the Late Cretaceous in the Western Interior Seaway of North America. In: Caldwell, W.G.E. \& Kauffman, E.G. (eds) Cretaceous Evolution of the Western Interior Basin of North America. Geological Association of Canada, Special Papers, 39, 333-353.

Roth, P.H. 1978. Cretaceous nannoplankton biostratigraphy and oceanography of the northwestern Atlantic Ocean. In: Benson, W.E. \& Sheridan, R.E. ET AL. Initial Reports of the Deep Sea Drilling Project, 44. US Government Printing Office, Washington, DC, 731-760.

Schlanger, S.O. \& Jenkyns, H.C. 1976. Cretaceous oceanic anoxic events: causes and consequences. Geologie en Mijnbouw, 55, 179-184.

Schlanger, S.O., Arthur, M.A., Jenkyns, H.C. \& Scholle, P.A. 1987. The Cenomanian/Turonian Oceanic Anoxic Event, I. Stratigraphy and distribution of organic carbon-rich beds and the marine $\delta^{13} \mathrm{C}$ excursion. In: Brooks, J. \& Fleet, A.J. (eds) Marine Petroleum Source Rocks. Geological Society, London, Special Publications, 26, 371-399.

Scholle, P.A. \& ARThur, M.A. 1980. Carbon-isotope fluctuations in Cretaceous pelagic limestones: potential stratigraphic and petroleum exploration tool. AAPG Bulletin, 64, 67-87.

Stoll, H.M. \& Schrag, D.P. 2000. High resolution stable isotope records from the Upper Cretaceous rocks of Italy and Spain: glacial episodes in a greenhouse planet? Geological Society of America Bulletin, 112, 308-319.

WATKINS, D.K. 1985. Biostratigraphy and paleoecology of calcareous nannofossils in the Greenhorn marine cycle. In: Pratt, L.M., Kauffman, E.G. \& Zelt, F.B. (eds) Fine-grained Deposits and Biofacies of the Cretaceous Western Interior Seaway: Evidence of Cyclic Sedimentary Processes. SEPM Field Trip Guidebook, 4, 151-156. 